\title{
Hepatitis a seropositivity and characteristics among healthcare workers in a training and research hospital in Istanbul
}

\author{
Ahmet Melih Sahin ${ }^{1 *}$, Ayse Tekin², Cem Basmaci ${ }^{3}$ Nuray Uzun Kes ${ }^{4}$, Emine Sonmez $^{5}$
}

\begin{abstract}
Objective: In this study, we investigated the relationship between the socioeconomic status, living conditions, life span, working life timeand the seropositivity of HEPATITIS A Virus (HAV) infection among our hospital staff members.

Material and Methods: Anti-HAV IgG testing of randomly selected 167 healthcare workers were examined in 2012-2013. All participants answered on a questionnaire consisting questions on transmission routes and socioeconomic status.

Results: Overall HAV seropositivity was found to be \%43.1 among healthcare workers with a mean age of 33.4for subjects with positive results and 27.4 years with negative results. Observed risk factors for seropositivity were the life span, professional working life time, life time in Istanbul, history of living in rural areas and frequent toilet usage outside of the house $(\mathrm{p}<0.05)$. The factors that are inversely associated with seropositivity were educational level of parents, being born in Aegean-Mediterranean region, bottled water share in drinking water consumption and being a physician $(\mathrm{p}<0.05)$.

Conclusion: In conclusion, HAV infections contniue to be a serious problem.Vaccination must be considered for seronegative healthcare workers and the public.

Key words:Hepatitis A Virus, Healthcare Workers, Risk Factors, Prevalence Seroepidemiologic Studies, Turkey
\end{abstract}

\section{Introduction}

Hepatitis A Virus (HAV) is an acute viral hepatitis factor commonly seen around the world and in Turkey. Our country falls within the moderate endemic group in terms of HAV epidemiology. $37 \%$ of the world's population still do not have connect to adequate sanitation and $11 \%$ is without access to any source of clean drinking water (1). Therefore, infectious diseases transmitted by faecal-oral route continue to constitute a problem (2).

In our country, seroprevalence of HAV increases with the school-age and, although reported differently in various studies, reaches the rates above $90 \%$ during adulthood $(3,4)$. However, recent studies showed that a significant decrease is started to be observed in this rate $(5,6,7,8)$.

In this study, we examine the connection between the socioeconomic status, working and living conditions and the seropositivity of HAV infection among healthcare workers working at Şişli Hamidiye Etfal Training and Research Hospital.

\section{Material and Methods}

In this study, Anti-HAV IgG results of 167 healthcare workers worked at Şişli Hamidiye Etfal Training and Research Hospital in 2012-2013 were examined. AntiHAV IgG was studied in serum samples with

ELISA method using DiaSorin, Saluggia, Italy kit and LiaiSon Immunoassay instrument. A questionnaire was applied to 167 participants, which contains questions on transmission routes and socioeconomic status.

Statistical method: Mean and standard deviation values were used in the explanatory statistics of data. Kolmogorov-Smirnov test was used for distribution of variables, Mann-Whitney U test was used for analysis of quantity of data, and Chi-square test and Fisher's

Received 25-04-2016 Accepted 26-05-2016 Available Online 15-08-2016

1 Prof. Dr. A. İlhan Özdemir State Hospital, Dept of Infectious Diseases and Clinical Microbiology, Giresun, TR

2 Cengiz Gokcek Obstetric and Children's State Hospital, Dept of Infectious Diseases and Clinical Microbiology,

Gaziantep, TR

3 Dr.Ersin Aslan State Hospital, Dept of Internal Medicine, Gaziantep, TR

4 Şişli Hamidiye Etfal Training and Research Hospital, Dept of Infectious Diseases and Clinical Microbiology, Istanbul, TR

5 Recep Tayyip Erdoğan University Medical School, Dept of Infectious Diseases and Clinical Microbiology, Rize, TR

* Corresponding Author: Ahmet Meli Sahin E-mail: ahmetmelihsahin44@hotmail.com Phone: +90 5055042202 
exact test were used for analysis of qualitative data. SPSS 22.0 program was used in the analyses.

\section{Results}

Demographics of healthcare workers participated in study such as age, gender and place of birth and residence are provided in Table 1.

Anti-HAV IgG result was determined to be negative for 95 participants and positive for 72 participants. Mean age was 27.4 years for healthcare workers with negative Anti-HAV IgG result and 33.4 years for healthcare workers with positive

Anti-HAV IgG result. Age of the personal of AntiHAV IgG positive group was determined to be higher than the individuals in Anti HAV IgG negative group $(\mathrm{p}<0.05)($ Table 1$)$.

No important distinction was saw in gender distribution between the healthcare workers with negative and positive Anti-HAV IgG result $(\mathrm{p}<0.05)$ (Table 1).
Anti-HAV IgG positivity rate was lower in individuals born in Aegean-Mediterranean region as compared to individuals born in the other regions $(\mathrm{p}<0.05)$ (Table $1)$.

Anti-HAV IgG positivity was higher in individuals who lived in a village at some point in their lives when compared to individuals who never lived in a village $(\mathrm{p}<0.05)$ (Table 1$)$.

Period of time spent in Istanbul was longer in AntiHAV IgG positive group compared to Anti HAV IgG negative group $(\mathrm{p}<0.05)$ (Table 1$)$.

Among the healthcare workers, Anti-HAV IgG positivity was lower for physicians when compared to other occupational groups $(\mathrm{p}<0.05)$ (Table 2).

Professional time was detected to be longer in AntiHAV IgG positive group in comparison to Anti HAV IgG negative group ( $<<0.05)$ (Table 2 ).

Table 1: Some demographic characteristics of healthcare workers participated in study

\begin{tabular}{|c|c|c|c|c|c|c|c|c|}
\hline \multirow[b]{3}{*}{ Age } & & \multicolumn{6}{|c|}{ Hepatitis A } & \multirow{3}{*}{$\begin{array}{c}\mathrm{p} \\
0.000\end{array}$} \\
\hline & & \multicolumn{3}{|c|}{ Anti-Hav IgG(-) } & \multicolumn{3}{|c|}{ Anti-Hav IgG(+) } & \\
\hline & & 27.4 & \pm & 4.2 & 33.4 & \pm & 6.9 & \\
\hline \multirow{3}{*}{ Gender } & & $\mathrm{n}$ & & $\%$ & $\mathrm{n}$ & & $\%$ & \multirow{3}{*}{0.193} \\
\hline & Female & 67 & & 59.8 & 45 & & 40.2 & \\
\hline & Male & 26 & & 49.1 & 27 & & 50.9 & \\
\hline \multirow{5}{*}{$\begin{array}{l}\text { Place } \\
\text { of Birth }\end{array}$} & Aegean-Mediterranean & 25 & & 73.5 & 9 & & 26.5 & 0.028 \\
\hline & Central Anatolia & 10 & & 41.7 & 14 & & 58.3 & 0.164 \\
\hline & $\begin{array}{l}\text { Southeastern Anatolia - Eastern } \\
\text { Anatolia - Eastern Black Sea }\end{array}$ & 24 & & 52.2 & 22 & & 47.8 & 0.448 \\
\hline & Marmara - Western Black Sea & 36 & & 59.0 & 25 & & 41.0 & 0.673 \\
\hline & Bulgaria & 0 & & 0.0 & 2 & & 100.0 & \\
\hline \multirow{3}{*}{$\begin{array}{l}\text { Living } \\
\text { Area }\end{array}$} & Always lived in a city & 66 & & 61.1 & 42 & & 38.9 & 0.136 \\
\hline & $\begin{array}{l}\text { Lived in a town for some time or } \\
\text { permanently }\end{array}$ & 24 & & 66.7 & 12 & & 33.3 & 0.181 \\
\hline & $\begin{array}{l}\text { Lived in a village for some time or } \\
\text { permanently }\end{array}$ & 5 & & 21.7 & 18 & & 78.3 & 0.000 \\
\hline \multirow{2}{*}{\multicolumn{2}{|c|}{$\begin{array}{l}\text { How long do you live in Istanbul (years)? } \\
\text { Mann-Whitney U test / Chi-square test }\end{array}$}} & 10.2 & \pm & 9.6 & 17.2 & \pm & 12.1 & 0.000 \\
\hline & & & & & & & & \\
\hline
\end{tabular}


Table 2: Occupational distribution and professional time of healthcare workers

\begin{tabular}{|c|c|c|c|c|c|c|c|}
\hline \multirow[b]{3}{*}{ Professional Time } & \multicolumn{6}{|c|}{ Hepatitis A } & \multirow{3}{*}{$\begin{array}{l}\mathrm{p} \\
0.000\end{array}$} \\
\hline & \multicolumn{3}{|c|}{ Anti-Hav IgG(-) } & \multicolumn{3}{|c|}{ Anti-Hav IgG(+) } & \\
\hline & 4.1 & \pm & 3.9 & 9.0 & \pm & 7.1 & \\
\hline Profession & $\mathrm{n}$ & & $\%$ & $\mathrm{n}$ & & $\%$ & \\
\hline Physician & 58 & & 65.2 & 31 & & 34.8 & 0.021 \\
\hline Nurse - Lab. Technician & 28 & & 53.8 & 24 & & 46.2 & 0.594 \\
\hline Allied Health Personnel & 0 & & 0.0 & 16 & & 100.0 & 0.000 \\
\hline Secretary & 9 & & 90.0 & 1 & & 10.0 & 0.029 \\
\hline
\end{tabular}

Table 3: Nutritional habits of healthcare workers

\begin{tabular}{|c|c|c|c|c|c|c|}
\hline & & \multicolumn{4}{|c|}{ Hepatitis A } & \multirow{3}{*}{$\mathrm{p}$} \\
\hline & & \multicolumn{2}{|c|}{ Anti-Hav IgG(-) } & \multicolumn{2}{|c|}{ Anti-Hav IgG(+) } & \\
\hline & & $\mathrm{n}$ & $\%$ & $\mathrm{n}$ & $\%$ & \\
\hline \multirow{2}{*}{ Water Consumption } & Bottled Water & 62 & 68.1 & 29 & 31.9 & \multirow{2}{*}{0.001} \\
\hline & Municipal Water-Other & 33 & 43.4 & 43 & 56.6 & \\
\hline \multirow{4}{*}{ Habit of Eating Out } & Less than once a week & 14 & 32.6 & 29 & 67.4 & \multirow{4}{*}{0.001} \\
\hline & Once a week & 21 & 67.7 & 10 & 32.3 & \\
\hline & 2-3 times a week & 34 & 58.6 & 24 & 41.4 & \\
\hline & 4 or more times a week & 26 & 74.3 & 9 & 25.7 & \\
\hline \multirow{2}{*}{$\begin{array}{l}\text { Location of Toilet at the Place } \\
\text { You Lived in the Past }\end{array}$} & Inside the house & 93 & 60.4 & 61 & 39.6 & \multirow{2}{*}{0.002} \\
\hline & Outside the house & 2 & 15.4 & 11 & 84.6 & \\
\hline
\end{tabular}

Table 4: Income distribution of healthcare workers

\begin{tabular}{|c|c|c|c|c|c|c|}
\hline & & \multicolumn{4}{|c|}{ Hepatitis A } & \multirow{3}{*}{$\mathrm{p}$} \\
\hline & & \multicolumn{2}{|c|}{ Anti-Hav IgG(-) } & \multicolumn{2}{|c|}{ Anti-Hav $\operatorname{IgG}(+)$} & \\
\hline & & $\mathrm{n}$ & $\%$ & $\mathrm{n}$ & $\%$ & \\
\hline \multirow{4}{*}{ Monthly Income } & $<1000$ & 2 & 33.3 & 4 & 66.7 & \multirow{4}{*}{0.504} \\
\hline & $1000-2500$ & 34 & 53.1 & 30 & 46.9 & \\
\hline & $2500-5000$ & 50 & 61.0 & 32 & 39.0 & \\
\hline & $>5000$ & 9 & 69.2 & 4 & 30.8 & \\
\hline \multirow{3}{*}{ How many people live in your household? } & 3 & 19 & 50.0 & 19 & 50.0 & \multirow{3}{*}{0.022} \\
\hline & $4-5$ & 66 & 64.7 & 36 & 35.3 & \\
\hline & $>6$ & 10 & 37.0 & 17 & 63.0 & \\
\hline
\end{tabular}

Table 5: Educational level of parents of healthcare workers

\begin{tabular}{|c|c|c|c|c|c|c|}
\hline & & \multicolumn{4}{|c|}{ Hepatitis A } & \multirow{3}{*}{$\mathrm{p}$} \\
\hline & & \multicolumn{2}{|c|}{ Anti-Hav IgG(-) } & \multicolumn{2}{|c|}{ Anti-Hav IgG(+) } & \\
\hline & & $\mathrm{N}$ & $\%$ & $\mathrm{n}$ & $\%$ & \\
\hline \multirow{5}{*}{ Educational Status of Mother } & None & 8 & 30.8 & 18 & 69.2 & \multirow{5}{*}{0.000} \\
\hline & Primary school & 31 & 47.7 & 34 & 52.3 & \\
\hline & Secondary school & 14 & 58.3 & 10 & 41.7 & \\
\hline & High school & 21 & 80.8 & 5 & 19.2 & \\
\hline & University & 21 & 80.8 & 5 & 19.2 & \\
\hline \multirow{5}{*}{ Educational Status of Father } & None & 1 & 25.0 & 3 & 75.0 & \multirow{5}{*}{0.000} \\
\hline & Primary school & 17 & 32.7 & 35 & 67.3 & \\
\hline & Secondary school & 9 & 69.2 & 4 & 30.8 & \\
\hline & High school & 25 & 75.8 & 8 & 24.2 & \\
\hline & University & 43 & 66.2 & 22 & 33.8 & \\
\hline
\end{tabular}


Healthcare workers were asked questions addressing the infrastructure services such as their drinking water source, habit of eating out, and toilet use and location. Anti-HAV IgG positivity rate was lower in individuals who mainly drink bottled water as compared to individuals who use other sources of water $(\mathrm{p}<0.05)$ (Table 3). Anti-HAV IgG positivity rate was significantly high in individuals who used a toilet outside the house at some point in their life $(\mathrm{p}<0.05)$ (Table 3).

No difference was detected when healthcare workers were compared for their monthly income and number of people per household ( $\mathrm{p}<0.05)$ (Table 4).

Anti-HAV IgG positivity rate was detected to decrease as the educational level of the parents of healthcare workers increased $(\mathrm{p}<0.05)$ (Table 5).

\section{Discussion}

Although 1,400,000 new hepatitis A virus infections consist globally every year, the prevalence of Hepatitis A tends to decrease except for the underdeveloped and developing countries (2). This was associated with improvements in adherence to hygiene rules, decrease in infrastructure problems, and increases in socio-economic development and educational level. Although our country belongs to the moderate endemic group, various seropositivities were detected in the studies conducted in different regions $(5,6,7)$. Various studies in healthcare workers and community in our country show that the anti-HAV IgG positivity increases with the age, reaching the rates above $90 \%$ in adult population $(4,5,6,7)$.

In a study evaluating the prevalence of anti-HAV IgG positivity in healthcare workers and students, antiHAV IgG was detected to be positive in $92.2 \%$ of the nurses, for whom the mean age was higher, and $57.5 \%$ of the nursing students (9).

In our study, mean age of healthcare workers with positive anti-HAV IgG result was found to be markedly higher than the group with negative antiHAV IgG result ( $\mathrm{p}<0.05)$ (Table 1).

HAV seropositivity is reported within the range of $7.8 \%$ to $88 \%$ in different regions of our country (11). In our study, seronegativity rates were higher in healthcare workers born in Aegean and Mediterranean regions $(\mathrm{p}<0.05) \quad($ Table 1$)$. This was attributed to more developed socio-economic status of these regions.In their study, Ozkınay et al. (12) found significantly higher rates for anti-HAV IgG positivity in individuals living in villages. In another study conducted in Iran, prevalence was determined to be markedly higher in the region with infrastructure problems (13). In our study, anti-HAV IgG positivity rate was found to be higher in individuals who lived in a village at some point in their lives and in individuals who lived in Istanbul for a longer timeof time ( $\mathrm{p}<$ $0.05)$. This was considered as an indication that the infrastructure and sanitation problems are not only experienced in villages but also in mega-villages, where population grows rapidly, such as Istanbul.Anti-HAV IgG positivity rate was found to be higher in healthcare workers with a longer professional time $(\mathrm{p}<0.05)$ (Table 2$)$.

As with the other infectious diseases, this may indicate that the occupational exposure increases with the increased professional time. It is reported that the educational status of parents, especially the mother, is closely associated with Anti-HAV IgG positivity rate and the prevalence decreases as the educational level increases $(11,12)$.

A study conducted in USA showed that the seropositivity was decreased as the years of school attendance of parents increased (14).

In a study performed by Erdogan et al. (15), it was observed that the HAV seropositivity was decreased as the educational level of mother increased.

Our study determined that the HAV seronegativity was increased with the increased educational level ( $\mathrm{p}$ $<0.05$ ) (Table 5). This can be explained by the fact that the better life conditions can be ensured as the educational level increases because it leads to improvements in awareness of diseases transmitted by faecal-oral route, personal hygiene, water and food hygiene, and socio-economic status. Study of Erdogan et al. (15) detected a markedly higher prevalence in low- and low-moderate-income individuals $(59.4 \%$ and $30.8 \%$, respectively).

In the study of Aldeniz et al. (4), a significant difference was determined between the groups with good and poor economic conditions (80.2\% and 94\%). In a study performed in Spain, a higher seropositivity was detected in people, who were born outside Spain and who were from a lower social class (16).

Our study found no important relationship between Anti-HAV IgG positivity and monthly income ( $\mathrm{p}>$ 0.05 (Table 4).Seronegativity was found to be significantly higher in individuals who drink prepared/bottled water $(\mathrm{p}<0.05)$ (Table 3$)$.

Also in other studies, seronegativity was found to be higher in groups composed of individuals drinking clean and safe water $(14,15,17)$.

\section{Conclusion}

In conclusion, the incidence of hepatitis A infections can be decreased by resolving the infrastructure problems, increasing the educational level and improving the hygiene conditions.

Improvements in these conditions delay the onset of disease to a later age during adulthood in our country. Vaccination of susceptible adults can be recommended when considering the fact that the course of disease become more serious in adulthood. This is even more important for healthcare workers with seronegative results and the disease and its complications can be decreased with the vaccination 
programs for this population. We believe that the vaccination programs will ensure immunisation of both the healthcare workers and the public, and contribute to eradication of disease over time and will also decrease the related complications, mortality and cost.

Conflict of Interest: The authors declare no potential conflicts of interest with respect to the research, authorship, and/or publication of this article.

Ethical issues: All Authors declare that Originality of research/article etc... and ethical approval of research, and responsibilities of research against local ethics commission are under the Authors responsibilities. The study was completed due to defined rules by the Local Ethics Commission guidelines and audits.

\section{Aknowledgement: None}

\section{References}

1. WHO, Global analysis and assesment of sanitation and drinking water (GLAAS):The challenge of extending and sustaining services. 2012 ISBN:9789241503365. http://apps.who.int/iris/bitstream/10665/44849/1/97892415 03365_eng.pdf?ua $=1$

2. Tosun S. Hepatit A virüs enfeksiyonu, "Tabak F, Tosun S (eds). Viral Hepatit", p.215-46, Viral Hepatitle Savaşım Derneği Yayını, İstanbul Medikal Yayıncılık, İstanbul (2013).

3. Sidal M, Unuvar E, Oğuz F, Cihan C, Onel D, Badur S Age-specific seroepidemiology of hepatitis A, B and E infections among children in İstanbul, Turkey. Eur J Epidemiol 2001;17(2):141-144.

4. Aldenizli C, Çavuşlu Ş, Altunay H, Özsoy MF, Yüksel D Badur S, et al. İstanbul'da $A$ ve $E$ hepatitlerin seroprevalans1. Viral Hepatit Dergisi 1998(1):31-36.

5. Mistık R. Türkiye'de viral hepatit epidemiyolojisi Yayınların irdelenmesi, “Tabak F, Balık İ, Tekeli E (eds) Viral Hepatit", p.9-50, Viral Hepatitle Savaşım Derneği Yayını, İstanbul Medikal Yayıncılık, İstanbul (2007).

6. Mistık R, Balık İ: Türkiye'de viral hepatitlerin epidemiyolojik analizi. Ed:Tekeli E, Balı İ:Viral Hepatit 2003. Roche, İstanbul 2003;9-56.
7. Dökmetaş İ. HAV Enfeksiyonunun epidemiyolojisi Yayınların irdelenmesi, "Tabak F, Balık I, Tekeli E (eds). Viral Hepatit”, p.51-61, Viral Hepatitle Savaşım Derneği Yayını, İstanbul Medikal Yayıncılık, İstanbul (2007).

8. Koçdoğan FY, İstanbul'da farklı yaş gruplarında Hepatit A prevalansı ve sosyo-ekonomik faktörlerle ilişkisi. Uzmanlık Tezi. Haydarpaşa EAH, 2006, İstanbul.

9. Öncü S, Öztürk B, Aydemir M, Öncü S, Sakarya S. Sağlık çalışanları ve öğrencilerinde Anti HAV IgG prevalansı. Viral Hepatit Dergisi 2004(3):162-165.

10. Kanra G, Tezcan S, Badur S; Turkish National Study Team: Hepatitis A seroprevalence in a random sample of the Turkish population by simultaneous EPI cluster and comparison with surveys in Turkey. Turk $\mathbf{J}$ Pediatr 2002;44(3):204-210.

11. Akbulut A: HAV İnfeksiyonu. Ed: Tekeli E, Balık İ: Viral Hepatit 2003. Roche, İstanbul, 2003;57-84

12. Özkınay F, Kurugöl Z, Koturoglu G ve ark. İzmir'de farklı yaş gruplarında hepatit A prevalansı ve sosyoekonomik faktörlerle ilişkisi. Adana II. Ulusal Çocuk İnfeksiyon Hastalıkları Kongresi Kongre kitabı 2001, Adana: 50-52

13. Mehr AJ, Ardakani MJ, Hedayati M, Shahraz S, Mehr EJ, Zali MR : Age spesific seroprevalence of hepatitis A infection among children visited in pediatric hospitals of Tehran, Iran. Eur J Epidemiol 2004;19(3):275-278.

14. Fix AD, Martin OS, Gallicchio L, Vial PA, Lagos R: Agespecific prevalence of antibodies to hepatitis A in Santiago, Chile; risk factors and shift in age of infection among children and young adults. Am J Trop Med Hyg 2002;66(5):628-632.

15. Erdogan MS, Oktun M, Tatman-Otkun M, Akata F, Ture M: The epidemiology of hepatitis A virus infection in children, in Edirne, Turkey. Eur $\mathrm{J}$ Epidemiol 2004;19(3):267-73

16. Dominguez A, Bruguera M, Plans P, Espuñes J, Costa J, Plasencia A, et al. Declining hepatitis A seroprevalence in adults in Catalonia(Spain): a population- based study. BMC Infectious Diseases 2007;7:73

17. Atabek ME, Findik D, Gulyuz A, Erkul I: Prevalence of anti-HAV and anti HEV antibodies in Konya, Turkey. Health Policy 2004;67(3): 265-269. 